\title{
THE ELEMENT OF MALICE IN THE LAW OF LIBEL IN CONNECTICUT.
}

Chief Justice Swift, in his digest of the laws of Connecticut published in the year I822, gives the following definition: "A libel is a malicious defamation in printing or writing, by signs or pictures, tending to injure the reputation of another; and everything written or published concerning another which renders him ridiculous, exposes him to public hatred or contempt and tends to hinder mankind from associating with him is actionable." The object of this article is to inquire into the meaning of the term "malicious" in the above definition. A thorough understanding of the meaning of this term is most important, as it is really the basis of the whole law of libel. The other elements that go to make it up are comparatively simple, - the fact of the printing or writing, and the nature of the charge, for instance,-but the element of malice is not so easily understood or proved.

Of course the word "malice" in ordinary conversation has a certain definite and well-defined meaning that everybody understands. It is pretty nearly equivalent to hatred, ill-will or spite, and when it is said that a man acts maliciously the meaning is that he acts with the deliberate intention of injuring some one. Where it is possible to prove the existence of this state of mind, with the other necessary facts, it is sufficient to support an action for libel. It is, of course, difficult to arrive at this result directly, because the matter lies entirely in the mind of the person charged, and therefore his own admission is the only direct evidence attainable. But there are many facts, the existence of which will raise a presumption that malice was present in the mind of the defendant, as for instance, such previous relations between the parties as would naturally cause him to have a desire for revenge. Acts and declarations of the defendant tending to prove that he desired to injure the plaintiff would also be admissible. There has been some doubt as to whether evidence of a subsequent repetition of the libel is admissible for any purpose when there is a count in the declaration embracing it. There is a series of five or six decisions 
on this point, the last of which is Ward v. Dick (47 Conn. 300), and it seems to be now pretty well settled that such evidence is admissible, but only for the purpose of showing the defendant's malice at the time he made the charge declared on, and not as a ground for the recovery of additional damages.

The presumption arising from the proof of the above facts may be rebutted by the defendant, and the absence of malice established, by showing that he had an honest and well-founded belief in the truth of the charge, and that he was actuated by a proper motive in making it, as for example, a desire to protect the public against the depredations of a thief or forger. It is a curious fact that the right to plead the truth of a claimed libel as a defense is secured by the constitution of this State (Article I., Section 7). We may notice in passing that this insertion of a provision of this nature in the fundamental law of the State is one of the earliest examples of tendency to depart from the original theory of the nature of a constitution which has grown to surprising proportions of late years, especially in the West.

It is of course, a self-evident fact that the publication of a false and scandalous charge against a man by a person who bears him no especial ill-will may injure him just as much in his reputation and feelings as it would do if the motive for the publication had been the most malignant malice, in the sense in which $I$ have heretofore used the term. The courts have always recognized this fact, and therefore they have given a somewhat extended and technical meaning to the term "malice" as used in actions for libel, which it is important to remember. Thus it was gradually established by judicial opinions that malice might be inferred from the simple fact that the charge was false. And if the defendant knew that the charge was false when he made it, and was actuated by improper and unjustifiable motives, or if he manifested indifference as to the effect the charge might have on the reputation of the plaintiff, and refused to retract it when requested, all these facts might be shown to strengthen the inference.

In actions for libel the plaintiff might recover for damages in two ways. First, actual damages, such as might accrue from the loss of employment as a direct result from the publication of the libel, and second, general damages, which were supposed to compensate him for the injury to his reputation and feelings. Actual damages had to be specially alleged and proved, but as it was difficult to prove general damages, their existence was inferred, and their amount generally depended on the character of the charge, and the motives which actuated the defendant in making it. 
Until the year 1855 the law of libel in Connecticut was developed by judicial opinions pretty nearly upon the lines of the common law and up to that time there were no enactments upon the subject with the exception of the constitutional provision I have referred to. But in that year a statute was passed which, at first sight, appears to introduce a radical change in the law of malice in actions for libel, though as I shall show by an examination of the decisions on this act, the change is not as great as at first sight appears. The act in question is in the following words:

"In every action for alleged libel the defendant may give proof of intention, and unless the plaintiff shall prove malice in fact, he shall recover nothing but his actual damage proved and specially alleged in his declaration."

Another act on the subject was passed in 1872 which it is not necessary to consider here, and which was incorporated in the above act in the revision of 1875 . These provisions have been retained in our statute law, and may be found in the revision of I888, Sec. II 6 .

At this distance of time it is of course impossible to discover anything as to the history of this statute, that is, who drafted it, and what his purpose was in obtaining its enactment. But in the decisions which are hereafter referred to it is said that it was intended solely as a protection to the publishers of newspapers who printed statements merely as items of current news, and with no intention of injuring anyone. If this is the truth about the intention of the draftsman, it is a very good example of how not to draw a statute, for a cursory examination of the wording will show that it is very much more far-reaching than it was intended to be. Judge Ellsworth seemed to have a pretty decided idea as to the undesirability of this act, for in his opinion in the first case in which it came under the notice of the Supreme Court (Moore v. Stevenson, 27 Conn. $\mathrm{r}_{4}$ ), he says: "As we have intimated, the law of libel was well enough as it stood before, and since it is a subject of peculiar difficulty and delicacy for legislation, it should be let alone, unless the evil suffered is very great, and that evil is (not) susceptible of a certain and equitable remedy."

The two cases in which this statute has been construed are Moore $v$. Stevenson (supra), and Hotchkiss v. Porter, 30 Conn. 4r4. These are the leading cases on the subject, although the statute is referred to and commented on in nearly all the subsequent decisions on libel, and they will fully repay a most careful 
examination by anyone who desires to be informed on the law of this subject. It was claimed by the defendant in the first of the above cases that the act was to be so construed as to justify any publication however false and generally injurious, if the defendant believed the charge to be true, and if the plaintiff could not prove the existence of hatred, spite or ill-will towards him. It must be admitted that the wording of the statute will bear this construction, and even that it would be the usual and natural meaning of the words. But the court dissents from this view in the strongest possible language, holding in the first place that such a construction would be contrary to the constitutional provision that "all courts are to be open to grant redress for every injury to the person, property or reputation," and that even if it were not unconstitutional it would be the grossest kind of a violation of the right of every citizen to protect his good name and reputation, since it would make it dependent on the mere belief of anyone who desired to attack it, and it would be impossible to prove that the defendant did not honestly believe the charge, if he simply took the trouble to swear that he did. The construction that the court did put upon the statute is best stated in the second of the above opinions (Hotchkiss $v$. Porter, $3 \circ$ Conn. 4r 4 ), where on page $42 \mathrm{I}$ the court says:

"The phrase 'malice in fact' is a technical one, and as the common law stood before the passage of the act of 1855 , did not mean malignity, spite or hatred, but improper and unjustifiable motive; and such the court held was its meaning in the law in question. And they further held that all that the legislature had said thereby, or could constitutionally say, was, that the defendant in all cases might prove that his motives were proper and justifiable, within the well settled principles of the common law, and that the plaintiff, in order to the recovery of general damages, should show, by other evidence than mere legal presumption from the fact of publication, that the motives of the defendant were not proper and justifiable. By that decision (Moore $v$. Stevenson, supra) it was settled that under the act the right of the plaintiff to recover general damages shall not depend upon the mere legal presumption of improper and unjustifiable motive, derived from the fact of publishing that which is untrue, but upon the question whether such improper and unjustifiable motive has been proved or disproved as a matter of fact by the evidence adduced for that purpose on the trial; that the legislature did not intend to prescribe any new rule as to the kind or degree of malice, or as to the character or kind of evidence by which the existence of improper and unjustifiable motive should be proved; that all that they intended was that the fact of improper and unjustifiable motive should appear in proof, and not be presumed; but whether in proof from the character of the libel, the res gesta or cireumstances attending its preparation and publication, or from evidence of other facts tending to show the real motive of the publisher, they did not intend to say; and that upon that construction the act was not invalid." 
From this it will be seen that the law on this subject was not much changed by the statute of 1855 after all, the only difference being that now the plaintiff must prove an additional fact, which is easily susceptible of proof if it really exists, though the last part of the extract quoted seems to intimate that if the libel and the circumstances of its publication are peculiarly outrageous, malice may be proved by that fact alone, in much the same manner that it might have been inferred from it before the statute was passed.

HaRTford, Conn.

Arthur Perkins. 